PNL-3263

UC-78

\title{
Optimization of Thorium \\ Oxalate Precipitation \\ Conditions Relative to \\ Thorium Oxide Sinterability
}

January 1980

Prepared for the U.S. Department of Energy under Contract EY-76-C-06-1830

Pacific Northwest Laboratory

Operated for the U.S. Department of Energy

by Battelle Memorial Institute 


\title{
NOTICE
}

This report was prepared as an account of work sponsored by the United States Government. Neither the United States nor the Department of Energy, nor any of their employees, nor any of their contractors, subcontractors, or their employees, makes any warranty, express or implied, or assumes any legal liability or responsibility for the accuracy, completeness or usefulness of any information, apparatus, product or process disclosed, or represents that its use would not infringe privately owned rights.

The views, opinions and conclusions contained in this report are those of the contractor and do not necessarily represent those of the United States Government or the United States Department of Energy.

\author{
PACIFIC NORTHWEST LABORATORY \\ operated by \\ BATTELLE \\ for the \\ UNITED STATES DEPARTMENT OF ENERGY \\ Under Contract EY-76-C-06-1830
}
Printed in the United States of America
Available from
National Technical Information Service
United States Department of Commerce
5285 Port Royal Road
Springfield, Virginia 22151

Price: Printed Copy 5

$\because$ Microfiche $\$ 3.00$

$\begin{array}{cc}\text { •Pages } & \begin{array}{c}\text { NTIS } \\ \text { Selling Price }\end{array} \\ 001-025 & \$ 4.00 \\ 026-050 & \$ 4.50 \\ 051-075 & \$ 5.25 \\ 076-100 & \$ 6.00 \\ 101-125 & \$ 6.50 \\ 126-150 & \$ 7.25 \\ 151-175 & \$ 8.00 \\ 176-200 & \$ 9.00 \\ 201-225 & \$ 9.25 \\ 226-250 & \$ 9.50 \\ 251-275 & \$ 10.75 \\ 276-300 & \$ 11.00\end{array}$


PNL-3263

$U C-78$

\section{1}

OPTIMIZATION OF THORIUM OXALATE

PRECIPITATION CONDITIONS RELATIVE

TO THORIUM OXIDE SINTERABILITY

G. D. White

L. A. Bray

P. E. Hart

January 1980

Prepared for

the U.S. Department of Energy

under Contract EY-76-C-06-1830

Pacific Northwest Laboratory

Richland, Washington 99352 
. 


\section{SUMMARY}

The effect of thorium oxalate precipitation conditions on derived oxide sinterability was investigated with the objective of producing $\mathrm{ThO}_{2}$ powder that could be sintered to high density without premilling. Precipitation conditions examined were temperature, digestion time and agitation method which were employed in a two-level factorial experimental design to delineate their effects. The two levels for each of the factors, respectively, were $10^{\circ} \mathrm{C}$ and $70^{\circ} \mathrm{C}, 15$ min and $360 \mathrm{~min}$, and mechanical stirrer and a homogenizer that imparted both mechanical and ultrasonic agitation. The $\mathrm{ThO}_{2}$ derived from each of the precipitation trials was characterized with respect to morphology, surface area, and crystallite size as well as sinterability. Only precipitation temperature had a significant effect upon all the properties of the derived oxide powders. The most sinterable oxide was derived from an oxalate precipitated at $10^{\circ} \mathrm{C}$ with mechanical agitation and 15 min digestion. Pellets formed from this oxide sintered to $96 \%$ TD. Physical property data were determined also for mixed oxide derived from coprecipitated thorium-25\% uranium (IV) oxalate and thorium oxide from continuously precipitated oxalate. 


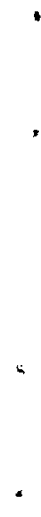


CONTENTS

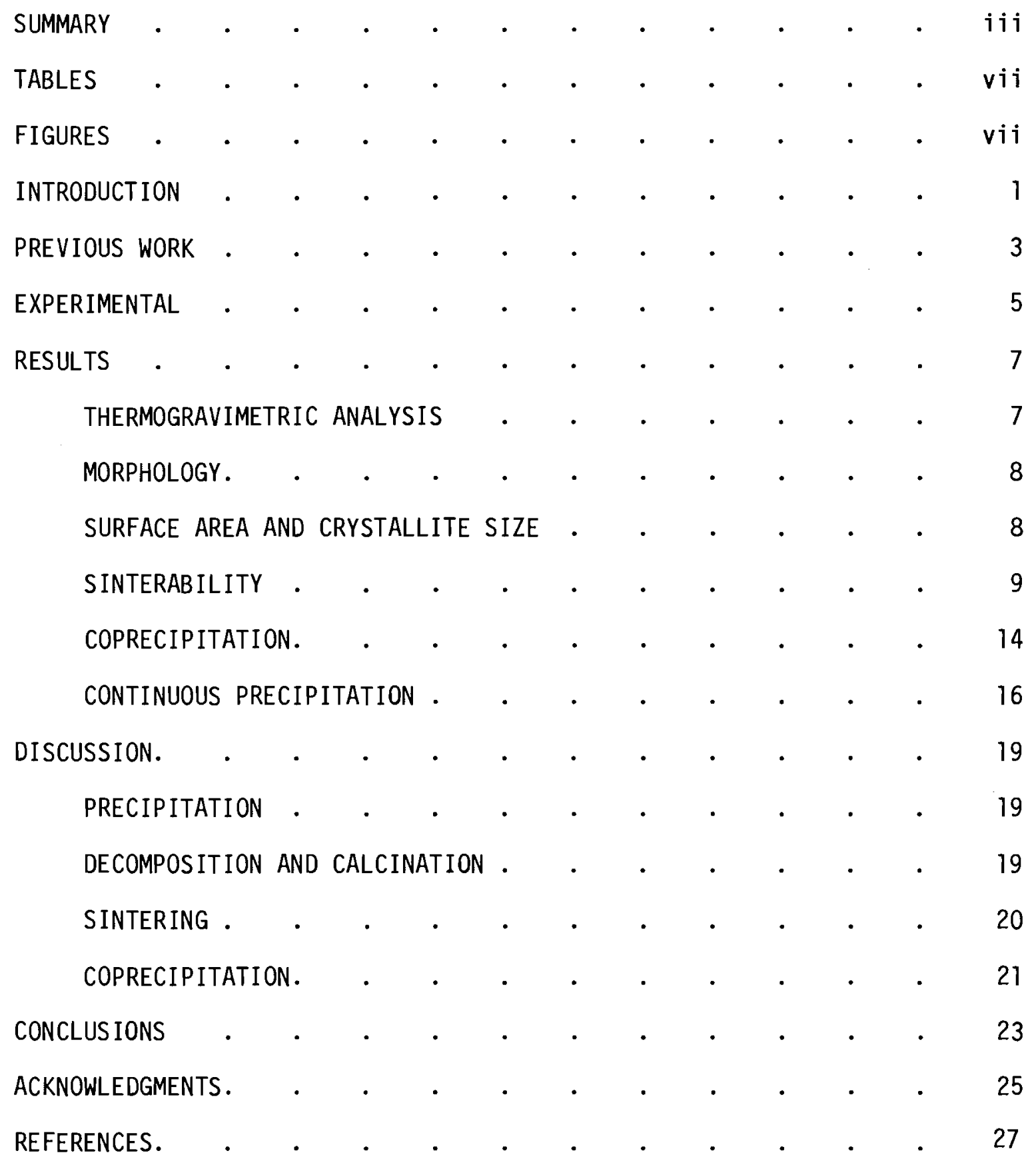

v 



\section{$\underline{\text { TABLES }}$}

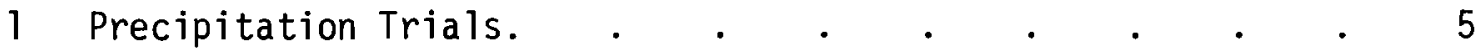

$2 \mathrm{ThO}_{2}$ Surface Area and Crystallite Size $\quad . \quad$. $\quad . \quad$. $\quad 9$

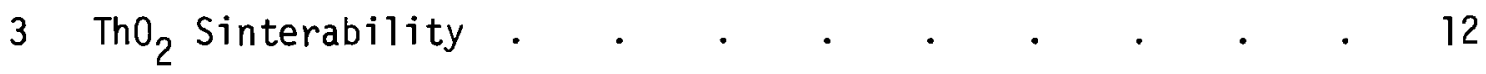

\section{FIGURES}

1 Weight Loss vs. Temperature For Thorium Nitrate and Thorium Oxalate, $2^{\circ} \mathrm{C} / \mathrm{min}$ in Air. $. \quad . \quad . \quad . \quad . \quad .7$

2 Scanning Electron Micrographs of Thorium Oxide Powder Derived From Thorium Oxalate Precipitated With The Following Conditions: (a) $10^{\circ} \mathrm{C}, 15$ min Digestion, Mechanical Agitation; (b) $70^{\circ} \mathrm{C}, 15 \mathrm{~min}$ Mechanical; (c) $10^{\circ} \mathrm{C}, 15 \mathrm{~min}$, Polytron; (d) $70^{\circ} \mathrm{C}, 15 \mathrm{~min}$, Polytron; (e) $10^{\circ} \mathrm{C}, 360 \mathrm{~min}$, Mechanical; (f) $70^{\circ} \mathrm{C}, 360 \mathrm{~min}$, Mechanical; (g) $10^{\circ} \mathrm{C}, 360 \mathrm{~min}$, Polytron; and (h) $70^{\circ} \mathrm{C}$, $360 \mathrm{~min}$, Polytron

3 Transverse Section of Thoria Pellet Fabricated of Powder Derived From Oxalate Precipitated at $10^{\circ} \mathrm{C}$ With Mechanical Agitation and 15 min Digestion . . . 13

4 Scanning Electron Micrographs of Thorium-25\% Uranium 0xide Powder Derived From Thorium-25\% Uranium (IV) Oxalate Coprecipitated at $10^{\circ} \mathrm{C}$ With Mechanical Agitation, 15 min Digestion, and Decomposed and Calcined

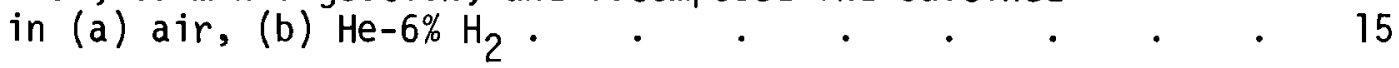

5 Scanning Electron Micrograph of Thoria Powder Derived From Thorium 0xalate Precipitated Continuously at $10^{\circ} \mathrm{C}$ With Mechanical Agitation.

6 Scanning Electron Micrograph of Thoria Powder Fused Together As A Result of Rapid Heating of Thorium Oxalate Hydrate. 


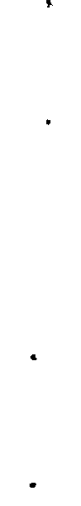




\section{OPTIMIZATION OF THORIUM OXALATE PRECIPITATION CONDITIONS \\ RELATIVE TO THORIUM OXIDE SINTERABILITY}

\section{INTRODUCTION}

Thorium, primarily in the form of $\mathrm{ThO}_{2}$, has been investigated and used experimentally as a nuclear fuel component over the past twenty years. In the Light Water Breeder Reactor at Shippingport, Pennsylvania, it is the fertile element, in solid solution with ${ }^{233} \mathrm{UO}_{2}$ in the core and as $100 \% \mathrm{ThO}_{2}$ in the blanket. More recently, thorium has been considered for use in a proliferation resistant fuel cycle as part of an alternative fuel program. In support of this objective, the Department of Energy's Fuels Refabrication and Development Program supported work at PNL (Pacific Northwest Laboratory) to develop simplified thoria fabrication procedures amenable to remote operation. The work reported here was part of this program.

Of prime importance in the development of a simplified thoria fabrication procedure is the sinterability of the starting powders. In the past, commercially produced thorium oxide powders have required extensive milling before they could be fabricated into dense pellets. These powders were produced primarily by the oxalate precipitation process. Thorium nitrate and oxalic acid solutions are reacted to precipitate thorium oxalate which after filtering is decomposed and calcined to produce thoria powder. The objective of this investigation was the refinement of the oxalate process to produce oxide power that sinters to high density without milling. The approach was to determine on a laboratory scale the effect on the derived thorium oxide sinterability of three oxalate precipitation parameters: precipitation temperature, agitation method and digestion time. This report describes the experimental precipitations and characterizes the derived thorium oxide powders with respect to sinterability, particle morphology, surface area, and crystallite size. Also included are the properties of $\mathrm{ThO}_{2}-25 \% \mathrm{UO}_{2}$ derived from coprecipitated thorium-25\% uranium (IV) oxalate and of $\mathrm{ThO}_{2}$ derived from continuously precipitated oxalate. 


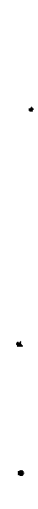




\section{PREVIOUS WORK}

Past investigators of the thorium oxalate precipitation method for making thorium oxide have been interested in oxide powder properties related to catalysis or slurry formation such as surface area, particle size, and particle morphology. Only one investigation has reported on the effect of a precipitation parameter on the sinterability of the derived thorium oxide powder.

Breysse, et al. (1) investigated the effect of various oxalate precipitation parameters on the surface area of the oxide powder after decomposing the oxalate at $350^{\circ} \mathrm{C}$. They concluded that the larger the precipitated thorium oxalate crystal, the larger the surface area. The results were interpreted by assuming that an oxalate crystal decomposes into an aggregate of thoria crystallites separated by dislocations on which gases can be adsorbed. During the investigation, they observed the decomposition on a hot stage microscope.

Allred and coworkers ${ }^{(2)}$ determined that the particles of the derived oxide powders increased in size with increasing oxalate precipitation temperature, being $1 \mu \mathrm{m}$ cubes from a $10^{\circ} \mathrm{C}$ precipitation increasing to $7 \mu \mathrm{m}$ platelets from a $100^{\circ} \mathrm{C}$ precipitation. Calcination of the decomposed oxalate at $400^{\circ}$ to $900^{\circ} \mathrm{C}$ had no effect upon the size or shape of the oxide particles for powders from the same precipitation, but the thoria crystallite size increased with increasing calcination temperature in all instances. 0xide powder surface areas decreased with increasing calcination temperature with the maximum rate of change occurring between $500^{\circ}$ and $700^{\circ} \mathrm{C}$. Surface areas were less than $10 \mathrm{~m}^{2} / \mathrm{g}$ for all oxides derived from oxalate precipitated at temperatures from $10^{\circ}$ to $100^{\circ} \mathrm{C}$ and calcined at $900^{\circ} \mathrm{C}$.

Becket and Winfield, (3) D'Eye and Sellman, (4) Moorehead and McCartney, (5) among several, have investigated the thermal decomposition of thorium oxalate. Upon heating in air, the oxalate loses water and forms the dihydrate below $200^{\circ} \mathrm{C}$; the dihydrate decomposes at $270^{\circ} \mathrm{C}$ to form the anhydrous oxalate. At $330^{\circ} \mathrm{C}$, oxalate decomposition proceeds by the formation of oxide directly or by the formation of carbonate which decomposes to the oxide. There was also evidence of $\mathrm{CO}$ disproportionating to form carbon and $\mathrm{CO}_{2}$ in $\mathrm{ThO}_{2}$ formed below $400^{\circ} \mathrm{C}$. 
Kantan, et al. (6) investigated the effect of oxalate precipitation temperature and calcination temperature on the sinterability of the derived oxide and concluded that the optimum combination of the two parameters was precipitation at $20^{\circ} \mathrm{C}$ followed by calcination at $900^{\circ} \mathrm{C}$. Using this set of conditions, they produced thoria powder which sintered to $94.7 \%$ TD. 


\section{EXPERIMENTAL}

A11 precipitations were direct strike using $\underline{1} \underline{M}$ oxalic acid and $1 \underline{M}$ thorium nitrate prepared by dissolving the respective salts in distilled water. Enough oxalate was precipitated in each trial to produce $40 \mathrm{~g}$ of oxide. The precipitation variables in the two level factorial experimental design were temperature, agitation, and digestion time. The trials are listed in Table 1.

Precipitation temperature control was effected using a seven liter Forma Scientific bath ${ }^{(a)}$ that circulated ethylene glycol through the double wall of a one liter glass reactor. The bath had a temperature range of -5 to $100^{\circ} \mathrm{C}$. Actual temperature of precipitation was measured with a thermometer submerged at the point of oxalate addition. Precipitation temperature and agitation were continued for the duration of digestion.

Two types of agitation were used, a conventional mechanical stirrer with a three-blade propeller turning at 350 rpm and a Brinkman Polytron ${ }^{(b)}$ running at 17,000 rpm. The Polytron imparts both mechanical and ultrasonic agitation.

\section{TABLE 1. Precipitation Trials}

\begin{tabular}{|c|c|c|c|}
\hline $\begin{array}{l}\text { Trial } \\
\text { Number } \\
\end{array}$ & $\begin{array}{c}\text { Temperature, } \\
{ }^{\circ} \mathrm{C} \\
\end{array}$ & $\begin{array}{l}\text { Digestion, } \\
\text { Minutes } \\
\end{array}$ & $\begin{array}{c}\text { Agitation } \\
\text { Method } \\
\end{array}$ \\
\hline 1 & 10 & 15 & Mechanical \\
\hline 2 & 10 & 15 & Polytron \\
\hline 3 & 70 & 15 & Mechanical \\
\hline 4 & 70 & 15 & Polytron \\
\hline 5 & 10 & 360 & Mechanical \\
\hline 6 & 10 & 360 & Polytron \\
\hline 7 & 70 & 360 & Mechanical \\
\hline 8 & 70 & 360 & Polytron \\
\hline
\end{tabular}

(a) Refrigerated-Heated Bath and Circulator, Forma Scientific, Inc., Marrietta, $\mathrm{OH}$.

(b) Model PT-45, Brinkman Instruments, Westbury, New York. 
The precipitates were filtered using a Buchner \#2 funnel with Whatman \#42 filter paper. Air was pulled through the filter overnight to achieve maximum filtrate removal. The thorium oxalate was dried at $115^{\circ} \mathrm{C}$, decomposed at $350^{\circ} \mathrm{C}$, and calcined at $900^{\circ} \mathrm{C}$, each for $24 \mathrm{hr}$ in air.

After sieving through a 40 mesh screen, the thoria was sampled to provide material for SEM examination, BET surface area measurement, and $x$-ray crystallite size determination.

Sinterability tests were done on the remaining thoria. Pellets were compacted at $276 \mathrm{MPa}(40,000 \mathrm{psi})$ from the as-sieved powder. Pellets also were compacted at $276 \mathrm{MPa}(40,000 \mathrm{psi})$ from powder that had been precompacted at $69 \mathrm{MPa}(10,000 \mathrm{psi})$, granulated through a 25 mesh sieve, and blended with $0.1 \%$ zinc stearate. All pellets were sintered in flowing $\mathrm{He}-6 \% \mathrm{H}_{2}$ at $1650^{\circ} \mathrm{C}$ for $3 \mathrm{hr}$. Pellet densities were calculated using the pellet weight and dimensions.

Thermogravimetric analyses were done on the thorium nitrate to determine molecular weight and on dried thorium oxalate precipitated at both $10^{\circ}$ and $70^{\circ} \mathrm{C}$ to confirm the oxalate decomposition temperatures. 


\section{RESULTS}

\section{THERMOGRAVIMETRIC ANALYSIS}

Thermogravimetric plots for thorium nitrate and thorium oxalate are shown in Figure 1. Weight loss for the thorium nitrate was equivalent to 6.86 water molecules per molecule of thorium nitrate which gives a molecular weight of 603. Duval ${ }^{(7)}$ reported that commercial thorium nitrate is a mixture of tetrahydrate and hexahydrate, therefore, a portion of the weight loss indicated may be adsorbed water. The arrest at $110^{\circ} \mathrm{C}$ is equivalent to a loss of two water molecules but the second arrest did not correlate with either the loss of the remaining water or the initiation of the nitrate decomposition. Conversion to thorium oxide was complete at approximately $625^{\circ} \mathrm{C}$.

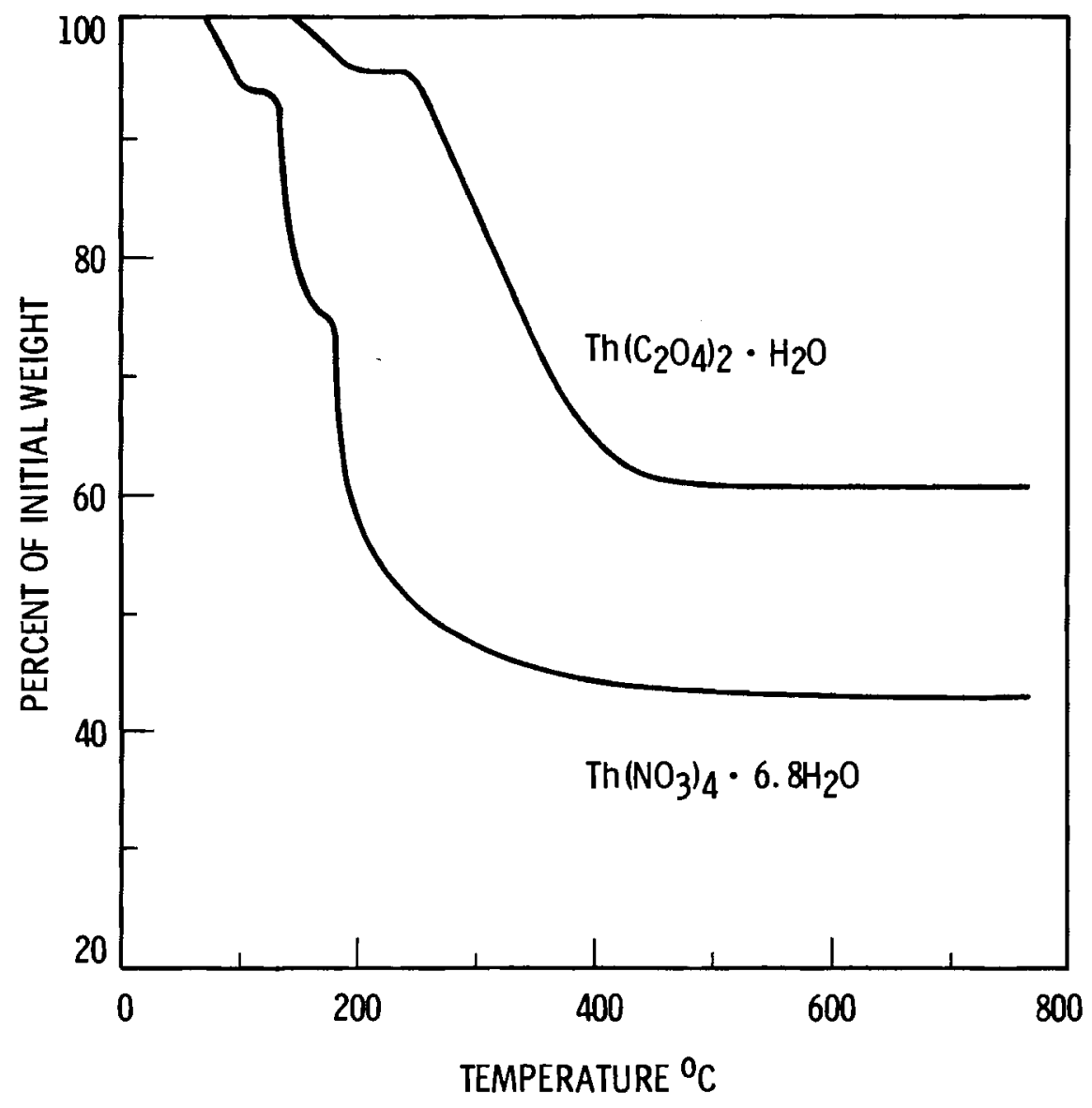

FIGURE 1. Weight Loss vs. Temperature For Thorium Nitrate and Thorium Oxalate, $2^{\circ} \mathrm{C} / \mathrm{min}$ in Air 
The weight loss for thorium oxalates precipitated at both $10^{\circ}$ and $70^{\circ} \mathrm{C}$ was closely equivalent to a monohydrate. The anhydrous oxalate decomposition commenced at approximately $250^{\circ} \mathrm{C}$ and was complete at $425^{\circ} \mathrm{C}$. A constant weight was achieved at approximately $600^{\circ} \mathrm{C}$. The temperature of precipitation had no appreciable effect on the weight loss temperatures of the two major decompositions.

MORPHOLOGY

Figure 2 shows scanning electron micrographs of thoria particles derived from the eight precipitations. Temperature of precipitation had the most graphic effect upon morphology. Oxide particles derived from the oxalate precipitated at $70^{\circ} \mathrm{C}$ are essentially square platelets, though the particles from oxalate precipitate digested 360 min and agitated by the Polytron are in some instances rounded. The platelets vary in size from 1-3 $\mu \mathrm{m}$ along the square edge. Particles from $10^{\circ} \mathrm{C}$ precipitations with mechanical agitation approximate cubes whereas those with Polytron agitation are mostly anhedral with the three axes near equal. In each instance, the particles are less than $1 \mu \mathrm{m}$ in size. The effect of Polytron agitation at $10^{\circ} \mathrm{C}$ on morphology was to inhibit the formation of euhedral crystals. However, the Polytron had no discernible effect upon the particles from the $70^{\circ} \mathrm{C}$ precipitation with a 15 min digestion. The effect of digestion time on morphology was slight. There does appear to be more uniformity in particle sizes from mechanically stirred precipitations digested 360 min compared to those digested $15 \mathrm{~min}$.

\section{SURFACE AREA AND CRYSTALLITE SIZE}

In Table 2, the surface area and $x$-ray crystallite size are listed for oxide powders derived from the precipitation trials. The surface area correlates strongly with oxalate precipitation temperature as well as digestion time. Oxalates from $10^{\circ} \mathrm{C}$ precipitations converted to oxide powders with more than twice the surface area of those from the $70^{\circ} \mathrm{C}$ precipitations and the 360 min digestion time increased the surface area of the derived powder by approximately one third over the powder from 15 min digestions. The surface areas 
TABLE 2. $\mathrm{ThO}_{2}$ Surface Area and Crystallite Size

\begin{tabular}{|c|c|c|c|}
\hline Conditions (a) & $\begin{array}{l}\text { Trial } \\
\text { No. } \\
\end{array}$ & $\begin{array}{c}\text { Surface } \\
\text { Area } \mathrm{m}^{2} / \mathrm{g}\end{array}$ & $\begin{array}{l}\text { Crystallite } \\
\text { Size } \AA \\
\end{array}$ \\
\hline $10 M 15$ & 1 & $8.69+.18$ & $201+20$ \\
\hline $10 \mathrm{P} 15$ & 2 & $9.26 \pm .12$ & $263+21$ \\
\hline $70 M 15$ & 3 & $3.00 \pm .14$ & $432+49$ \\
\hline $70 P 15$ & 4 & $3.57 \pm .14$ & $421 \pm 33$ \\
\hline $10 \mathrm{M} 360$ & 5 & $12.63+.28$ & $266+24$ \\
\hline $10 \mathrm{P} 360$ & 6 & $12.63+.12$ & $228+20$ \\
\hline $70 \mathrm{M} 360$ & 7 & $4.54+.14$ & $326+48$ \\
\hline $70 \mathrm{P} 360$ & 8 & $4.32+.12$ & $270+18$ \\
\hline
\end{tabular}

(a) First two digits temperature, $M$ or $P$ for mechanical or Polytron agitation and last digits for digestion time.

also had the normal inverse relationship to the primary particle sizes. The smaller crystallite sizes occurred in powders with smaller particle sizes. These results are similar to those reported by Allred, et al., although the surface areas and crystallite sizes are not exactly the same. In the present work, crystallite sizes are smaller (200 to $432^{\circ}$ vs. 500 to $\left.700 \mathrm{~A}\right)$ and surface areas encompass a broader range $\left(3.0\right.$ to $12.6 \mathrm{~m}^{2} / \mathrm{g}$ vs. 3.5 to $9.0 \mathrm{~m}^{2} / \mathrm{g}$ ) than the previous work for the same precipitation and calcination temperatures. Their precipitations were direct strike with dropwise addition of oxalic acid solution to the thorium nitrate and a $1 \mathrm{hr}$ digestion. The oxalates were decomposed at $375^{\circ} \mathrm{C}$ for $4 \mathrm{hr}$ followed by $16 \mathrm{hr}$ at $400^{\circ} \mathrm{C}$. These small variations in preparation procedure might account for the small differences in results. An additional source of difference would be the disparity in equipment used in making the measurements.

\section{SINTERABILITY}

The green and sintered densities for pellets pressed from the oxide powders are listed in Table 3. The highest green densities, 62-64\% TD, were achieved with powders from the $70^{\circ} \mathrm{C}$ precipitations. These powders were composed of 

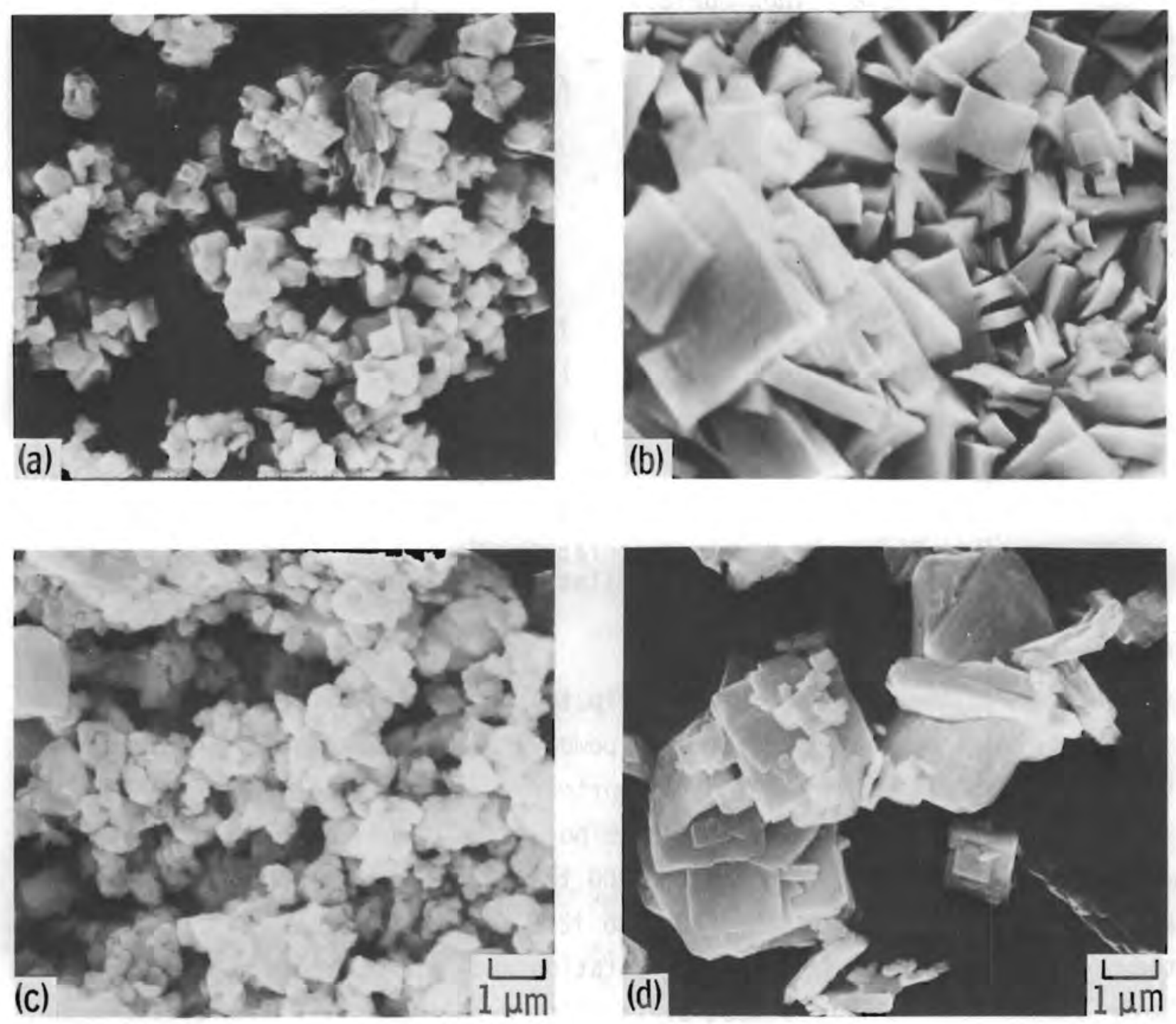

FIGURE 2. Scanning Electron Micrographs of Thorium 0xide Powder Derived From Thorium Oxalate Precipitated With The Following Conditions: (a) $10^{\circ} \mathrm{C}$ 15 min Digestion, Mechanical Agitation; (b) $70^{\circ} \mathrm{C}$, 15 min, Mechanical; (c) $10^{\circ} \mathrm{C}, 15 \mathrm{~min}$, Polytron; (d) $70^{\circ} \mathrm{C}, 15 \mathrm{~min}$, Polytron; (e) $10^{\circ} \mathrm{C}, 360 \mathrm{~min}$, Mechanical; (f) $70^{\circ} \mathrm{C}, 360 \mathrm{~min}$, Mechanical; (g) $10^{\circ} \mathrm{C}, 360 \mathrm{~min}$, Polytron; and (h) $70^{\circ} \mathrm{C}, 360$ min, Polytron 

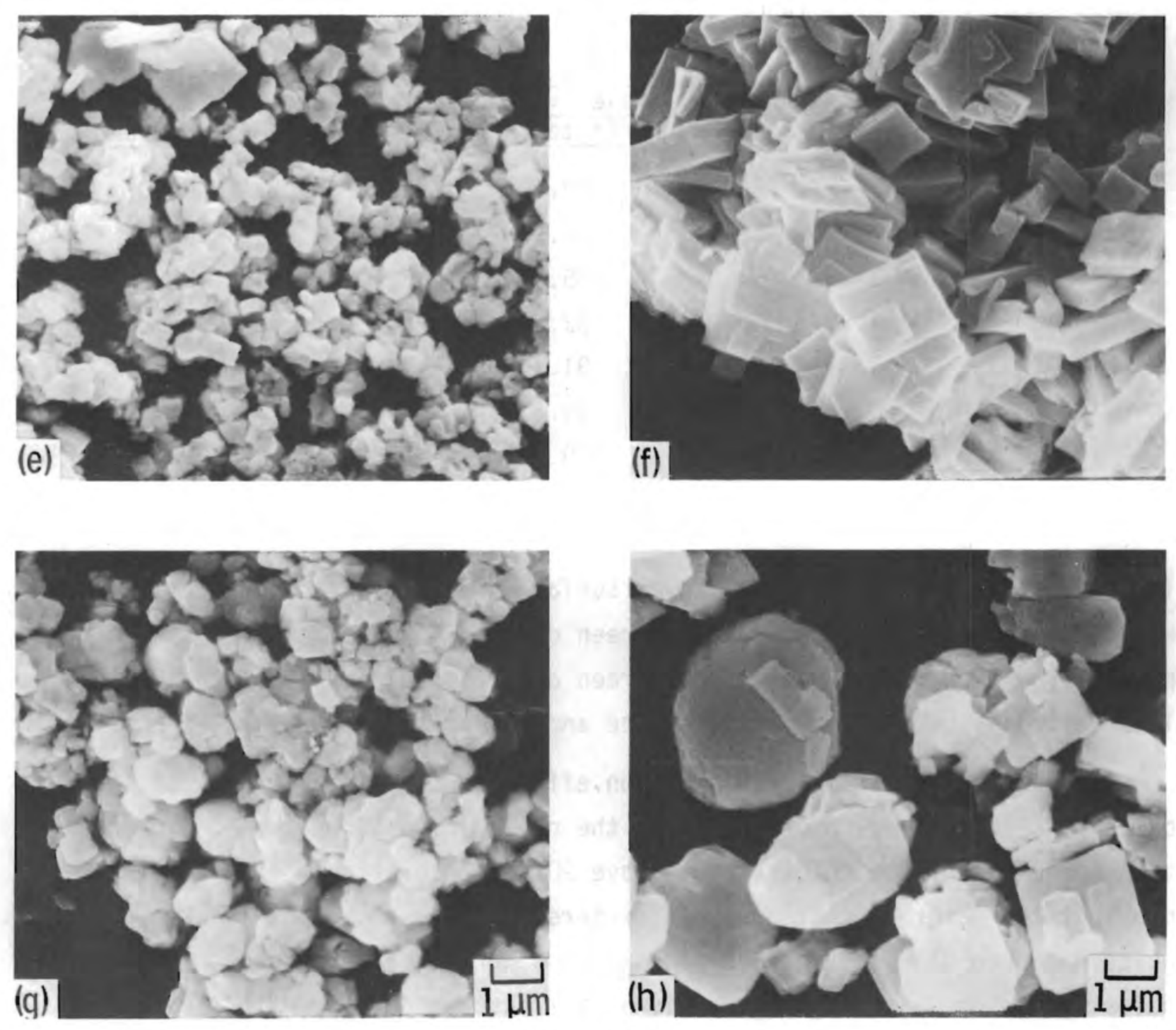

FIGURE 2. (contd) 
TABLE 3. $\quad \mathrm{ThO}_{2}$ sinterability

\begin{tabular}{|c|c|c|c|c|c|}
\hline \multirow[b]{3}{*}{ Conditions } & \multirow{3}{*}{$\begin{array}{c}\text { Trial } \\
\text { No. } \\
\end{array}$} & \multicolumn{4}{|c|}{$\%$ Theoretical Density } \\
\hline & & \multicolumn{2}{|c|}{ As-Sieved } & \multicolumn{2}{|c|}{$\frac{\text { Pre-Pressed \& Granulated }}{\text { Green }}$} \\
\hline & & Green & Sintered & Green & Sintered \\
\hline $10 M 15$ & 1 & 56.0 & 92.1 & 56.0 & 96.0 \\
\hline $10 P 15$ & 2 & 58.8 & 94.6 & 59.0 & 94.8 \\
\hline $70 M 15$ & 3 & 64.0 & 85.1 & 63.0 & 89.2 \\
\hline $70 P 15$ & 4 & 63.0 & 82.3 & 64.0 & 86.6 \\
\hline $10 M 360$ & 5 & 57.0 & 91.7 & 57.0 & 93.4 \\
\hline $10 \mathrm{P} 360$ & 6 & 56.5 & 94.6 & 56.0 & 95.9 \\
\hline $70 \mathrm{M} 360$ & 7 & 64.0 & 88.9 & 63.0 & 94.0 \\
\hline $70 \mathrm{P} 360$ & 8 & 62.0 & 81.4 & 63.0 & 93.0 \\
\hline
\end{tabular}

large, square platelets and had lower surface areas; both are properties that would have a positive effect on the green density. All of the pellets made of powder from $10^{\circ} \mathrm{C}$ precipitations had green densities of $56-59 \%$ of theoretical. This reflects the smaller particle size and higher surface area of the powders.

The most significant precipitation effect on the sinterability of the oxides was again temperature. All of the pellets made from the $10^{\circ} \mathrm{C}$ precipitation powders sintered to densities above $90 \%$ of theoretical. The on $1 y 70^{\circ} \mathrm{C}$ precipitated material that produced sintered pellets above $90 \%$ TD were powders which had been digested for 360 min and also were preslugged and granulated before pressing. Although there was an increase in density with preslugging and granulation for each of the powders, it was larger for the $70^{\circ} \mathrm{C}$ precipitated powders. This result undoubtedly is associated with the platelet morphology of the powder. Preslugging would prealign the short axes of the platelets with the pressing direction which, after granulation and final pressing, would produce overall a more intimate contact of the particles.

Figure 3 is a photomicrograph of transverse sections of a sintered pellet made from oxide powder derived from oxalate precipitated at $10^{\circ} \mathrm{C}$ with mechanical agitation and a 15 min digestion. Grain sizes range from $5 \mu \mathrm{m}$ to $40 \mu \mathrm{m}$ and are fairly evenly distributed. There are two populations of pores, very 


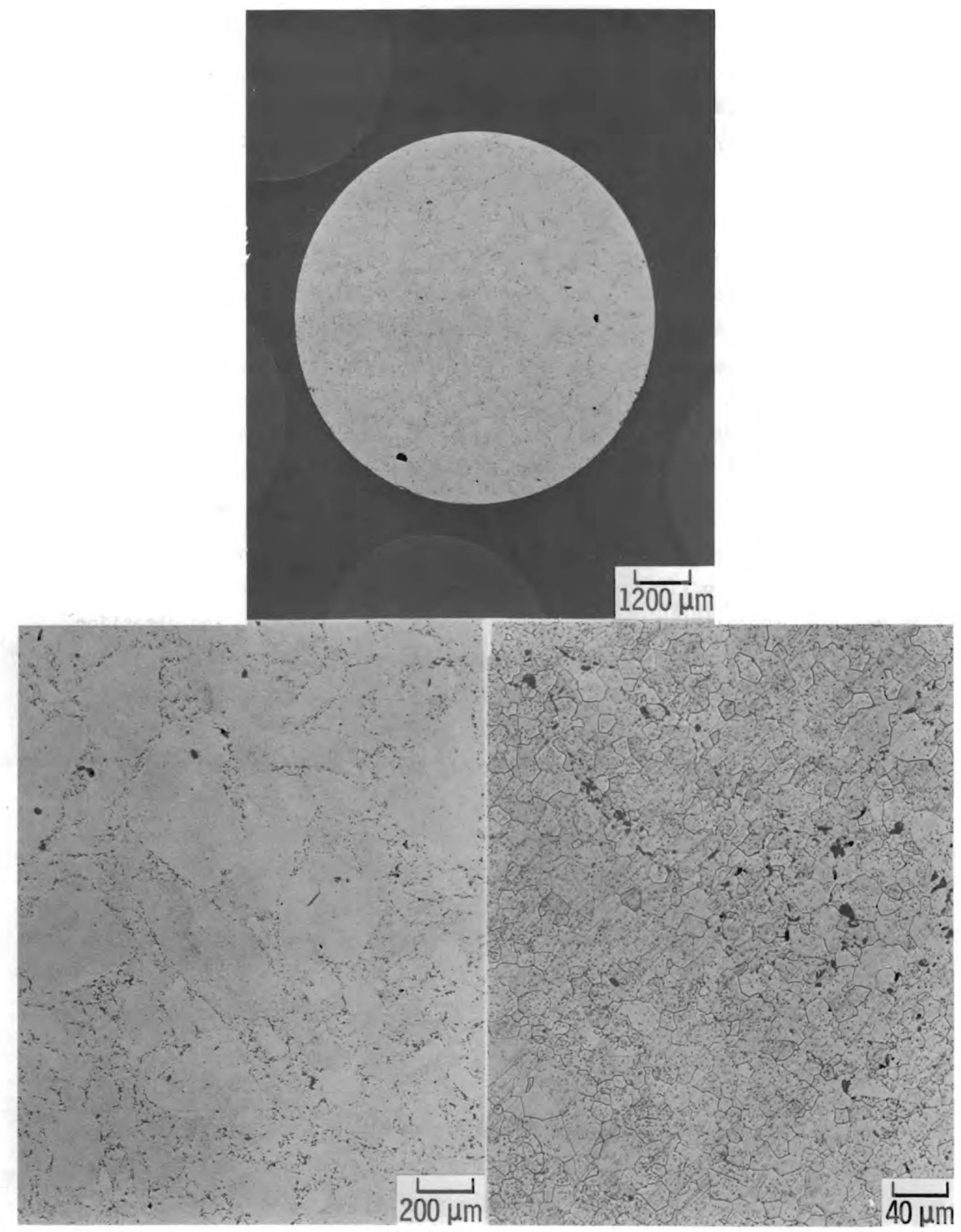

FIGURE 3. Transverse Section of Thoria Pellet Fabricated of Powder Derived From Oxalate Precipitated at $10^{\circ} \mathrm{C}$ With Mechanical Agitation and 15 min Digestion 
fine ones which are evenly distributed and coarse ones which appear to be mostly at the boundaries of the pressing granules. A longer time at sintering temperature possibly would eliminate some of the fine porosity.

\section{COPRECIPITATION}

A mixed oxide powder of $\mathrm{ThO}_{2}-25 \% \mathrm{UO}_{2}$ was prepared by coprecipitating the mixed oxalates. The procedure was the same as for the thorium oxalate precipitated at $10^{\circ} \mathrm{C}$ with mechanical stirring and 15 min digestion except the uranium in the mixed nitrate solution was prereduced ${ }^{(8)}$ using a two-fold excess of sodium formaldehyde sulfoxylate $\left(\mathrm{NaHSO}_{2} \cdot \mathrm{CH}_{2} \mathrm{O} \cdot 2 \mathrm{H}_{2} \mathrm{O}\right)$ and was held at room temperature for $24 \mathrm{hr}$. Half of the mixed oxalate was decomposed and calcined in air, the other half in He-6\% $\mathrm{H}_{2}$. The decomposition and calcination temperatures were $350^{\circ}$ and $900^{\circ} \mathrm{C}$, respectively, as with the thorium oxalates.

The morphologies of the particles from both powders, shown in Figure 4, are identical and are similar to the morphology of thoria particles derived from oxalate precipitated at the same temperature, agitation, and digestion time. The color of the air calcined powder was an orange brown whereas the powder calcined with a reducing atmosphere was a bluish green. X-ray diffraction patterns of each of the powders contained only reflections for a single face-centered cubic phase. The air calcined powder had a smaller unit cell size indicating a higher uranium oxidation state than in the powder calcined in a reducing atmosphere. Cohen and Berman ${ }^{(9)}$ concluded from their work on oxidation of $\mathrm{ThO}_{2}-\mathrm{UO}_{2}$ solid solutions that at any one uranium-thorium ratio, the unit cell size decreases linearly with the addition of excess oxygen. One method they used for determining the degree of oxidation was polarographic analysis for $\mathrm{U}^{+6}$ in the oxidized samples.

Chemical analysis of the two powders for carbon content showed the air calcined oxide contained $27 \mathrm{ppm}$ carbon compared to $5550 \mathrm{ppm}$ for the oxide calcined in $\mathrm{He}-6 \% \mathrm{H}_{2}$. This, along with the lower oxidation state of the uranium, would account for the blue-green color of the reduced powder. The surface areas were $7.18 \mathrm{~m}^{2} / \mathrm{g}$ and $6.12 \mathrm{~m}^{2} / \mathrm{g}$ for the air calcined and the reduced powders, respectively, while the crystallite sizes were $246 \AA$ and $134 \AA$. 

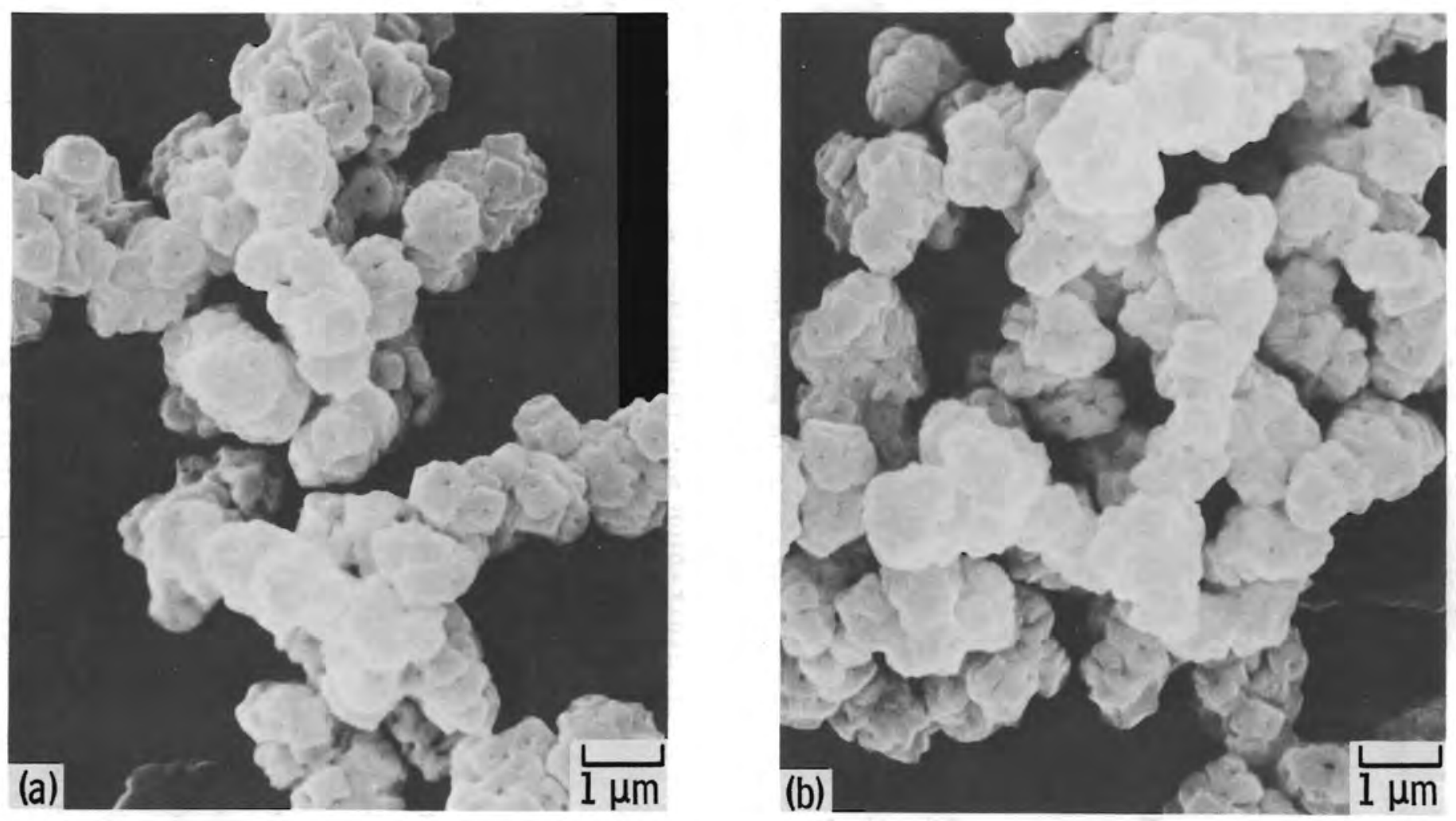

FIGURE 4. Scanning Electron Micrographs of Thorium-25\% Uranium Oxide Powder Derived From Thorium-25\% Uranium (IV) Oxalate Coprecipitated at $10^{\circ} \mathrm{C}$ With Mechanical Agitation, 15 min Digestion, and Decomposed and Calcined in (a) air, (b) $\mathrm{He}-6 \% \mathrm{H}_{2}$ 
Although there was some line broadening that could have resulted from lattice distortion, the relative sizes of the crystallites are probably accurate since the residual carbon should interfere with the growth of crystallites.

Sinterabilities for these powders were determined in the same manner as with the thoria powder except all pellets were pressed from preslugged and granulated powder. The as-pressed densities averaged $50 \%$ of theoretical and the sintered densities $94 \%$ of theoretical for the air calcined powder but only $70 \%$ of theoretical for the powder calcined in $\mathrm{He}-6 \% \mathrm{H}_{2}$. The carbon must have strongly interfered with the sintering since both of the powders were derived from the same precipitation and had similar particle morphologies, particle sizes, and surface areas.

\section{CONTINUOUS PRECIPITATION}

Thorium oxalate was precipitated continuously using the same double wall reactor employed in the direct strike precipitations. A $1 M$ solution of thorium nitrate and a $0.75 \mathrm{M}$ solution of oxalic acid were added simultaneously through separate dip sticks near the bottom of the reactor and the propeller of the mechanical stirrer. The precipitation was maintained at $10^{\circ} \mathrm{C}$ by the same circulating bath used during the direct strike precipitations. Metering pumps were calibrated to provide the necessary flow data for maintaining accurate molar flow ratios of the two solutions during the precipitation. To initiate the precipitation, a known volume of thorium nitrate solution was put in the reactor vessel and oxalic acid was added by the metering pump with mechanical stirring until all of the initial thorium was precipitated, whereupon the other pump was started and the two solutions were added simultaneously with continuous stirring. Intermittently, the precipitation product was withdrawn using a vacuum slurp line. Filtering, drying, decomposition, calcining, and testing for sinterability were done as for the previous precipitations.

The morphology of the particles produced by continuous precipitation were quite different from those produced by direct strike at the same temperature. Figure 5 shows SEM photomicrographs of thoria particles from precipitate taken 

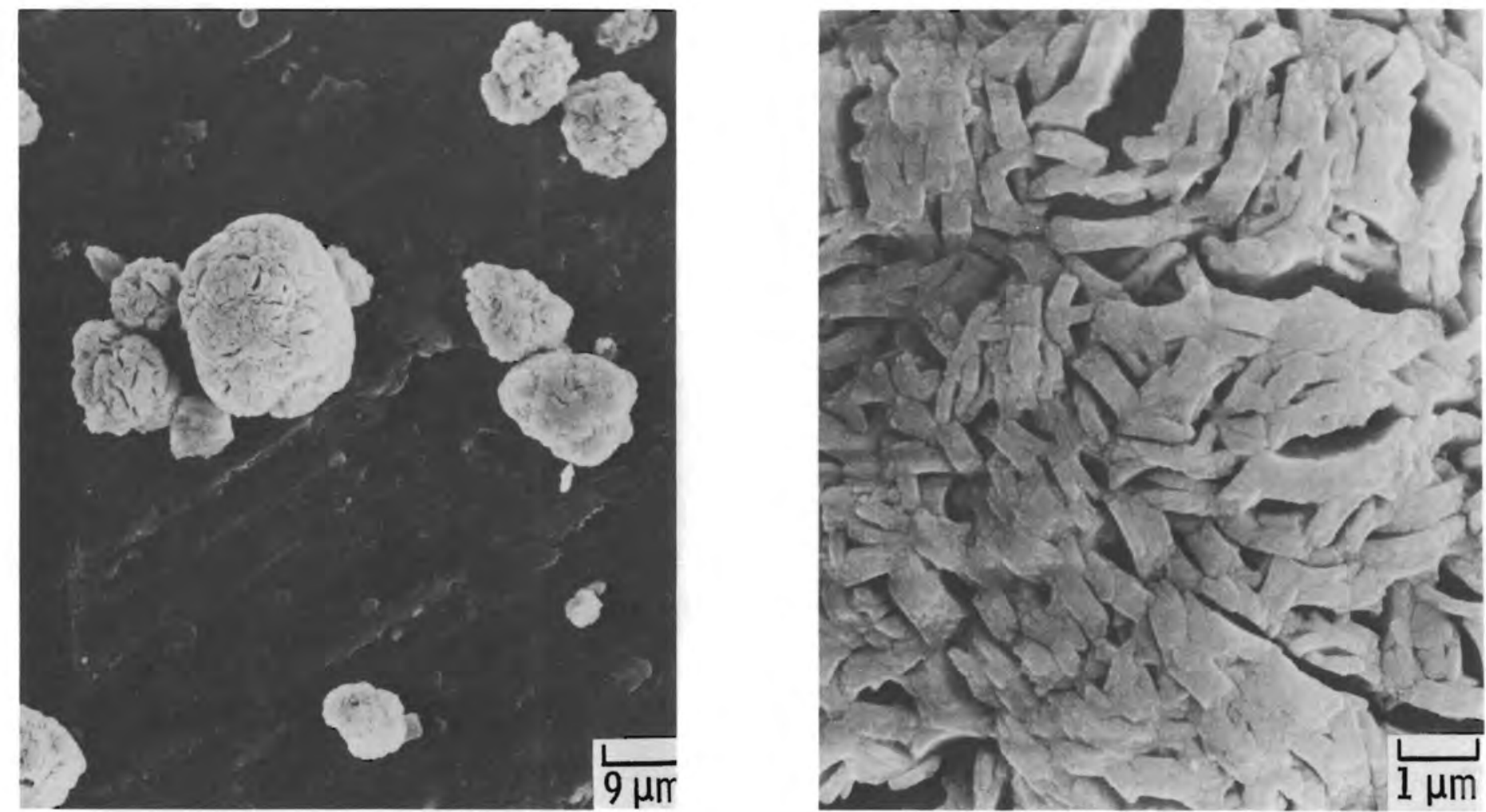

FIGURE 5. Scanning Electron Micrograph of Thoria Powder Derived From Thorium Oxalate Precipitated Continuously at $10^{\circ} \mathrm{C}$ With Mechanical Agitation 
from the last quarter of the run. Individual particles are agglomerates composed of intergrown platelets. The individual agglomerates range in size from $5 \mu \mathrm{m}$ to as much as $15 \mu \mathrm{m}$. However, the platelets range in thickness from 0.1 to $0.3 \mu \mathrm{m}$ and 1 to $3 \mu \mathrm{m}$ along the exposed platelet edge. The thoria crystallite size for this material was $205 \AA$ and the powder surface area 12.36 $\mathrm{m}^{2} / \mathrm{g}$. These two attributes were $201 \AA$ and $8.69 \mathrm{~m}^{2} / \mathrm{g}$ for the thoria derived from oxalate precipitated at $10^{\circ} \mathrm{C}$ by direct strike, mechanical stirring, and a 15 min digestion. Pellets made from the continuously precipitated product had green and sintered average densities of $60 \%$ and $95 \%$ of theoretical, respectively. 


\section{DISCUSSION}

\section{PRECIPITATION}

Duplicate precipitation trials were run at $10^{\circ} \mathrm{C}$ with 15 min digestion. The precipitation with mechanical stirring was easily duplicated producing material of similar sinterability as well as other properties. However, the precipitation with the Polytron agitation could not be duplicated in two attempts. The oxide powder produced in the duplicate trials was composed of large rectangular particles and had a low surface area and a poor sinterability. This inability to duplicate the initial precipitation was not definitely explained. However, the Polytron during the course of earlier trials had become coated with a thin layer of oxalate and precipitation temperature control became progressively more difficult. Both conditions could have affected the seeding rate for the precipitation resulting in particles with a different morphology. The Polytron design would not permit easy disassembly to perform complete dissolution of the oxalate coating. These results indicate that the precipitation equipment should be of simple design that permits complete removal of precipitate residue and should be made of material that resists oxalate adherence. Metal coated with a fluorinated hydrocarbon meets these requirements.

\section{DECOMPOSITION AND CALCINATION}

Thorium oxalate precipitated at $10^{\circ} \mathrm{C}$ was initially decomposed and calcined by inserting the dried oxalate monohydrate directly into a furnace at $900^{\circ} \mathrm{C}$. In the SEM photomicrograph, Figure 6, the particles obviously have fused together. This is thought to have resulted from the very rapid heating which caused the oxalate monohydrate to melt before it had time to decompose. Pellets made from this oxide sintered to densities of 1ess than $90 \%$ of theoretical. When the dried oxalate monohydrate was decomposed first at $350^{\circ} \mathrm{C}$ before calcining at $900^{\circ} \mathrm{C}$, the melting did not occur. Therefore, it is important in the production of sinterable thorium oxide powder from the oxalate that the decomposition and calcining heat cycle include enough time between 300 and $400^{\circ} \mathrm{C}$ to thoroughiy decompose the hydrated oxalate. 


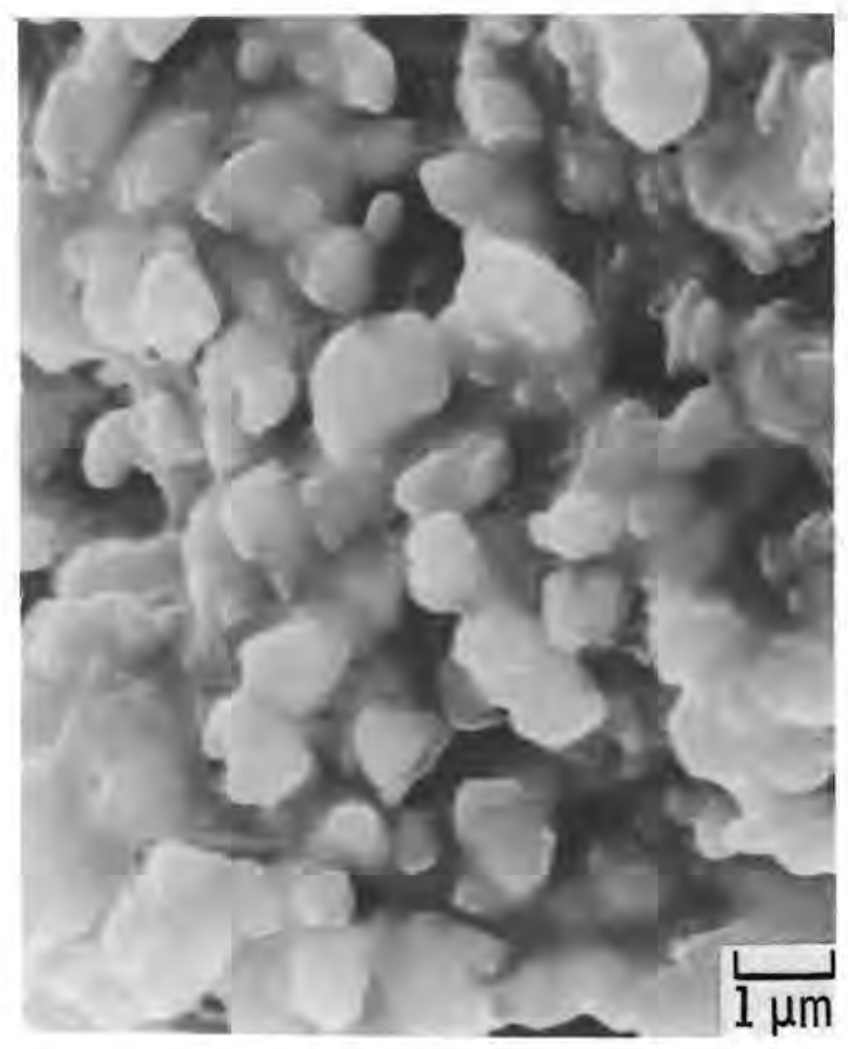

FIGURE 6. Scanning Electron Micrograph of Thoria Powder Fused Together As A Result of Rapid Heating of Thorium 0xalate Hydrate

Of equal importance is that the oxalate decomposition atmosphere be strongly oxidizing since traces of carbon remain even during decomposition in air. As was demonstrated, a sizable amount of carbon can be formed during decomposition in a reducing atmosphere and the presence of the residual carbon in the oxide strongly interferes with sinterability. In a production size calcining operation, even the slow removal of the $\mathrm{CO}$ and $\mathrm{CO}_{2}$ evolved on decomposition could cause reducing conditions in the powder and result in the retention of an unacceptable amount of residual carbon.

\section{SINTERING}

The results of these oxalate precipitation studies indicate that thorium oxide powders which will sinter to 95\% TD without premilling can be produced 
by controlling the precipitation parameters and the decomposition and calcining conditions. The most sinterable thoria was derived from oxalate precipitated at $10^{\circ} \mathrm{C}$ with mechanical stirring and 15 min digestion. Al though these conditions would be impractical to duplicate with a large batch production operation, similar production rates, with the same degree of control, could be achieved with a continuous precipitation reactor. The difference in the particle morphologies of the powders derived from the direct strike and the continuous precipitations had little effect upon their relative sinterabilities. It might be possible to duplicate the particle morphology of the direct strike with continuous precipitation by mixing the nitrate and oxalic acid solutions immediately before they enter the reactor.

\section{COPRECIPITATION}

The fact that the coprecipitated thorium and uranium (IV) oxalates can be decomposed and calcined in air and converted to a single phase oxide solution makes this an excellent method of producing the mixed oxide fuel. Formation of solid solution from the individual oxides can be accomplished only with extensive co-milling and reaction at $1700^{\circ} \mathrm{C}$ or above. ${ }^{(10)}$ The degree of homogeneity achieved with the coprecipitation undoubtedly would be superior to that achieved with the reaction of the separate oxides. 



\section{CONCLUSIONS}

- Of the thorium oxalate precipitation variables - temperature, agitation, and digestion time - temperature has the most effect upon particle morphology, surface area, crystallite size, and sinterability of the derived thoria powder.

- Among the thorium precipitation parameter combinations investigated, a $10^{\circ} \mathrm{C}$ temperature, mechanical stirring, and 15 min digestion are the combination that produces oxalate from which the most sinterable thorium oxide powder is derived. Pellets of $96 \%$ TD can be fabricated from this powder without premilling.

- Coprecipitated thorium-25\% uranium (IV) oxalate can be converted to a single phase mixed oxide solid solution by heating in air.

- The necessary parametric control can be achieved with continuous precipitation to produce oxalate that converts to sinterable thorium oxide powder.

- Simultaneous separate introduction of the oxalic acid and thorium nitrate solutions into the continuous precipitation reactor produces precipitated particles which are agglomerates of intergrown crystals distinctly different from the particles precipitated by direct strike.

- In the production of thorium oxide powder from oxalate, the decomposition and calcining heat cycle must include enough time between $300^{\circ}$ and $400^{\circ} \mathrm{C}$ to thoroughly decompose the oxalate hydrate. 


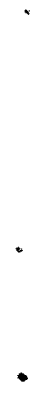

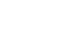




\section{ACKNOWLEDGMENTS}

The authors wish to recognize the contributions of several staff members to this work. The SEM work was contributed by J. E. Coleman and J. L. Daniel, $x$-ray diffraction by $H$. E. Kissinger, the surface area measurements by $C . W$. Griffin, the thermogravimetric plots by H. C. Buchanan, (a) and the metallography by D. H. Parks. The general lab work was done by W. J. Woods $(a)$ and T. R. Myers.

(a) Employees of Westinghouse Hanford Co. 


\section{$\underline{\text { REFERENCES }}$}

1. M. Breysse, B. Claudel and Y. Trambouze. Effect of Conditions for Precipitating a Salt on the Texture of Its Thermal Decomposition Product: the Case of Thorium Oxalate. WAPD-Tr-64, Bettis Atomic Power Laboratory, West Mifflin, PA, 1965.

2. V. D. Allred, S. R. Burton and J. P. McBride. "Characteristic Properties of Thorium Oxide Particles." J. Phys. Chem. 61:117-20, 1965.

3. R. Becket and M. E. Winfield. "The Thermal Decomposition of Thorium Oxalate." Austr. J. Sci. Res. 4:644-50, 1951.

4. R. W. M. D'Eye and P. G. Sellman. "The Thermal Decomposition of Thorium 0xalate." J. Inorg. Nucl. Chem. 1:143-48, 1955.

5. D. R. Moorehead and E. R. McCartney. "The Formation of Thoria by Decomposition of the Nitrate, Oxalate and Hydroxide." J. Aust. Ceram. Soc. $12: 27-33,1976$.

6. S. K. Kantan, R. V. Raghavan and G. S. Tendolkar. "Sintering of Thorium and Thoria." Proceedings of the Second United Nations International Conference on the Peaceful Uses of Atomic Energy. Vol. 6, pp. 132-138, United Nations, Geneva, 1958.

7. C. Duval. Inorganic Thermogravimetric Analysis. Second Edition, Translated from the French by R. E. Oesper, Elsevier Publishing Co., New York, NY, 1963.

8. S. F. Marsh, M. R. Ortiz and J. E. Rein. Coprecipitation of Uranium and Plutonium Oxalates Using Sodium Formaldehyde Sulfoxylate Reduction and Diethyl Oxalate Hydrolys is Precipitation. LA-5876-MS, 1975.

9. I. Cohen and R. M. Berman. "A Metallographic and X-Ray Study of the Limits of Oxygen Solubility in the $\mathrm{U}_{2}-\mathrm{ThO}_{2}$ System." J. Nucl. Mat. 18:77-107, 1966 .

10. R. G. R. Johnson and H. H. Crain. Fabrication of Solid, Annular, and Dished-End Ceramic Fuel Pellets. WAPD-TM-578, Bettis Atomic Power Laboratory, West Mifflin, PA, 1967. 


\section{DISTRIBUTION}

No. of

Copies

\section{OFFSITE}

A. A. Churm

DOE Chicago Patent Division

9800 South Cass Avenue

Argonne, IL 60439

27 Technical Information Center

$\underline{\text { ONSITE }}$

94 Pacific Northwest Laboratory

FRAD Program Office (50)

J. 0. Barner

L. A. Bray

D. W. Brite

T. D. Chikalla

N. C. Davis

- S. Goldsmith

C. W. Griffin

C. M. Hagen

C. R. Hann

P. E. Hart

K. A. Hsieh

R. S. Kemper

R. B. Matthews

C. L. Mohr

J. R. Nesbitt

R. E. Schreiber

H. H. Van Tuyl

G. D. White (20)

Technical Information (5)

Publishing Coordination YO (2) 
